\title{
Article
}

\section{Understanding the Impact of Independent Human Rights Institutions for Children: A European Study}

Imanian, Sara and Thomas, Nigel Patrick

Available at http://clok.uclan.ac.uk/28636/

Imanian, Sara and Thomas, Nigel Patrick ORCID: 0000-0002-5310-9144

(2019) Understanding the Impact of Independent Human Rights Institutions for Children: A European Study. The International Journal of Children's Rights, 27 (2). pp. 339-372. ISSN 0927-5568

It is advisable to refer to the publisher's version if you intend to cite from the work. http://dx.doi.org/10.1163/15718182-02702001

For more information about UCLan's research in this area go to http://www.uclan.ac.uk/researchgroups/ and search for <name of research Group>.

For information about Research generally at UCLan please go to http://www.uclan.ac.uk/research/

All outputs in CLoK are protected by Intellectual Property Rights law, including Copyright law. Copyright, IPR and Moral Rights for the works on this site are retained by the individual authors and/or other copyright owners. Terms and conditions for use of this material are defined in the policies page.

\section{CLoK}

Central Lancashire online Knowledge www.clok.uclan.ac.uk

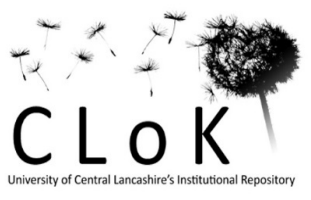




\title{
Understanding the impact of independent human rights institutions for children: a European study
}

\author{
Sara Imanian \\ Cumberland Council, NSW \\ imanians@gmail.com
}

Nigel Patrick Thomas

University of Central Lancashire, UK

npthomas@uclan.ac.uk

\begin{abstract}
This article reports a study of the impact of independent human rights institutions for children, using methods drawn from critical realism and appreciative inquiry. A survey of member institutions of the European Network of Ombudspersons for Children enquired into the contexts, mechanisms and outcomes of their work. The results showed wide variation in the situation, aims and methods of working of the institutions, along with some strong commonalities. The survey was followed by two in-depth case studies, to explore how staff and external stakeholders understood and evaluated the impact of their work. A conclusion was that the impact of such institutions has to be understood in a grounded way, and pre-designed general indicators are therefore of limited value. One product of the research is a template, developed collaboratively with the institutions, which can be used to understand and evaluate the effectiveness of their work.
\end{abstract}

\section{Keywords}

Children's rights - Children's Ombudsmen - Children's Commissioners - ICRIs - IHRICs impact evaluation 


\section{Introduction}

This article presents findings from a study of the impact of independent children's rights institutions (ICRIs) and independent human rights institutions for children (IHRICs), generally known as Ombudsmen or Commissioners for children. There is some debate about which term should be used, with some using IHRIC to refer to offices established as part of general human rights institutions and ICRIs to refer to specialist institutions for children (Thomas et al., 2011). In this paper we generally use 'IHRIC' to refer to both types, except where we are explicitly distinguishing the two. The Committee on the Rights of the Child refers to 'independent national human rights institutions for children'; however, many institutions operate at the level of a city, province or region, or a devolved or autonomous nation within the member State.

Such institutions have proliferated following the Convention on the Rights of the Child (CRC); especially since the Committee on the Rights of the Child called on States Parties to establish independent institutions 'for the promotion and monitoring of implementation of the Convention' (Committee on the Rights of the Child, 2002: 1). Nowhere has this proliferation been more rapid and extensive than in Europe. The European Network of Ombudspersons for Children (ENOC) was established in 1997 with 10 founding members. By 2012, when this research commenced, it had grown to 42 members in 32 States.

Where such institutions were already established, the Committee called on States to 'review their status and effectiveness for promoting and protecting children's rights' (ibid.). However, the evaluations that have been carried out are limited in number, scope and depth, and the institutions' impact has remained largely unexplored (Lansdown, 2001; Doek, 2008; Sedletzki, 2013). This is a serious omission, because it allows assumptions (positive or negative) about their impact and usefulness to go untested. Impact evaluation is important for individual institutions in understanding and directing their activities and justifying their claims for funding. It is also important for the children's rights movement as a whole in understanding the particular contribution of independent children's rights institutions and making the case for their existence.

Any general approach to evaluating impact has to take account of the wide variation in the contexts (social, political, cultural, economic) in which national institutions operate, and also 
in the powers, functions, mandate and resources available to the institutions. In Europe, all existing institutions have a function of promoting and safeguarding children's rights under the Convention; but some are able to pursue individual cases whilst others are confined to general advocacy, and their degree of independence from government is also variable. To be a full member of ENOC, an institution must comply with ENOC's Standards for Independent Children's Rights Institutions (2001) and with the Paris Principles adopted by the United Nations (1993). Institutions that approach these standards but fall short in some way are eligible for associate membership.

This study set out to explore how impact is understood by children's rights institutions, and to begin to develop methods and tools for evaluating impact, through a systematic, in-depth, comparative and collaborative study of institutions in Europe. Rather than seeing evaluation as a bureaucratic task for institutions to 'tick off', our research aimed to respect evaluation as 'essential to addressing a childhood in constant transformation' and 'crucial to meeting evolving challenges to institutional independence and sustainability' (Sedletzki, 2013: 49). We chose to conduct a survey of all members of ENOC, to get a broad picture of how institutions across Europe saw their priorities and understood their impact, and to provide a basis on which to recruit participants for phase 2 which was a case study looking in depth at impact evaluation in two institutions. In this article we first explain how the survey was initiated and conducted, and present the results. We then explain how the case studies were selected, and summarise the process and findings analytically. Finally we discuss the implications of the research for understanding impacts and how they may be evaluated in future, including a proposal for an impact evaluation tool.

\section{Methodology}

The approach taken in this research was informed by critical realism and realistic evaluation (Bhaskar, 1997, 1998; Pawson and Tilley, 1997; Robson, 2013). According to Mayall (2002) critical realism offers a helpful approach to studying childhood, as it encompasses change and continuity in children's experiences and takes account of 'different features of structures i.e. the ideologies, policies, established practices regarding childhood' (p.39) and the power relations between adults and children, in addition to showing the strengths and weaknesses of agency. 
In social research informed by critical realism, context is important to understanding how mechanisms work to facilitate or hinder actions that lead to an outcome (C-M-O configurations) (Pawson and Tilley, 1997; Robson, 2002). Hewitt et al. (2012) have shown that evaluating the outcomes through paying attention to mechanisms and (social and political) context can help to demonstrate what works well, for whom and in what circumstances.

The survey was accordingly designed to yield information about contexts, mechanisms and outcomes as understood by respondents, and so to enable at least some initial exploration of 'C-M-O configurations'. It is not claimed that this research fully employed the methods of realistic evaluation. However, the 'C-M-O' schema provided a useful way in which to conceptualise the work of children's rights institutions and to analyse the survey responses. The opening questions asked about contextual factors in which the institutions operated: their principal sources of assistance and obstacles, the CRC and other frameworks which they used, and the influence of different stakeholders on their work. The next set of questions concerned their methods of working and the mechanisms they sought to employ: this included the level of children's engagement in the organisation, the ways in which they used their ENOC membership and the kinds of impact that they sought, both in general and in relation to particular groups of children. The remaining questions focused directly on outcomes: what the staff of the institution considered to be their most significant impact on children, how they tried to evaluate or measure their impact, whether they had undergone any internal or external evaluation, whether this had been helpful, and whether any children's rights or other indicators were used in the evaluation. A final question asked about the institution's willingness to take part in a case study looking further into ways of evaluating their impact on childhood and children's lives. Further details of the case study methodology are given later in this article.

The questionnaire was intentionally brief in order to maximise responses from busy institutions. ${ }^{1}$ With some assistance from the ENOC office, it was emailed in May 2012 to all 42 members of ENOC, with an option to complete it either in English or in French. After several reminders, responses were eventually received from 28 member institutions. Ten were general institutions (IHRICs) and the remainder were specialist children's rights institutions

\footnotetext{
${ }^{1}$ The full questionnaire is available at https://www.uclan.ac.uk/research/explore/groups/ assets/survey-questionnaire.docx.
} 
(ICRIs); 22 operated at the State Party level, while six were based in a region or semiautonomous nation; 22 were full members and six were associate members. ${ }^{2}$ Six responses were completed by the Ombudsperson or Commissioner in person, four by a Deputy Ombudsperson responsible for children's rights, six by the head of a children's rights unit, nine by advisors and three by officers or coordinators.

The methodology used for the case study phase is explained later; first we present the results of the survey.

\section{Results of the survey}

\section{Contexts}

Institutions identified their main sources of assistance in their work as: their staff; their mandate and independence; international frameworks; stakeholders and networks at the local and national, European and international level. Institutions in newly established democracies in Eastern Europe and the Balkans were more likely to mention national and local government. Those who listed children as a source of assistance were mainly from Scandinavia and the United Kingdom.

The principal obstacles identified were organisational features and structural barriers. Organisational features included shortage of resources and deficiencies in national legal frameworks: almost all members reported inadequate budgets and insufficient staff as main obstacles; many pointed to the need for legislation and for the CRC to be taken into account by the courts. Structural barriers were seen as political, economic and cultural: lack of political will and co-ordination regarding children's policies and services, which 'leads to delays in the implementation of the Ombudsman's recommendations'; child poverty and impact of austerity; general lack of awareness of children's rights and negative attitudes to children and young people in society and the media.

\footnotetext{
2 The institutions that responded were from Armenia, Belgium (Flanders), Bosnia and Herzegovina, Croatia, Cyprus, England, Finland, Georgia, Greece, Hungary, Iceland, Ireland, Italy, Latvia, Lithuania, Luxembourg, Netherlands, Northern Ireland, Norway, Portugal, Republika Srpska (Bosnia), Scotland, Serbia, Slovakia, Slovenia, Sweden, Vojvodina (Serbia), and Wales.
} 
In addition to the $\mathrm{CRC}$ which was referred to by all respondents, the most common frameworks used were: CRC protocols, General Comments and Concluding Observations of the Committee on the Rights of the Child, Council of Europe Conventions and recommendations, EU law, and national legislation. Most respondents indicated that they sometimes felt a need to go beyond the rights set out in the $\mathrm{CRC}$ in order to have a clear framework for their work.

Participants were invited to rank the actual and ideal influence of the following stakeholders: children; NGOs; Government; the media; parents; religious organisations and churches. The analysis is shown in Table 1. IHRICs generally considered Government to be their most influential stakeholder, but their ideal was that children should have the most influence. For some institutions, children were seen as the most influential stakeholders, whilst for others children were the least influential; there was no obvious pattern in terms of regional location or type of institution.

Table 1. Stakeholders' actual and ideal influence: overall rankings

\begin{tabular}{ll}
\hline Ranking of actual influence & Ranking of ideal influence \\
\hline 1. Government & Children \\
2. NGOs & NGOs \\
3. Parents & Parents \\
4. Children & Government \\
5. Media & Media \\
6. Religious Organisations & Religious Organisations
\end{tabular}

\section{Mechanisms}

Questions here aimed to understand how institutions set their working priorities, strategies and collaborative approaches.

\section{Institutions' priorities}

Respondents were asked to rank the following aims (taken from ENOC's website) in order of priority:

1. To promote full implementation of the CRC;

2. To influence law, policy and practice; 
3. To promote a higher priority for children and more positive public attitudes;

4. To encourage government to give proper respect to children's views;

5. To promote awareness of children's rights among children and adults;

6. To monitor and promote children's access to advocacy and complaints processes;

7. To promote the rights of particular groups of disadvantaged children.

Table 2 shows the aggregated order of priority, followed by the rank order scores (calculated by summing the number of respondents alloting a particular ranking to each aim multiplied by that rank order - thus a higher number represents a lower priority). The final column indicates which institutions gave each aim as their first priority.

Table 2. Ranking of priorities by respondents

\begin{tabular}{|c|c|c|}
\hline Priorities (in aggregated rank order) & Scores & $\begin{array}{l}\text { Institutions ranking this as first } \\
\text { priority }\end{array}$ \\
\hline 1. To Influence law, policy and practice & 48 & $\begin{array}{l}\text { Armenia, Bosnia, Croatia, Netherlands, } \\
\text { Serbia }\end{array}$ \\
\hline $\begin{array}{l}\text { 2. To promote full implementation of the } \\
\text { CRC }\end{array}$ & 50 & $\begin{array}{l}\text { Cyprus, Finland, Greece, Italy, Latvia, } \\
\text { Norway, Northern Ireland, Srpska }\end{array}$ \\
\hline $\begin{array}{l}\text { 3. To promote awareness of children's } \\
\text { rights among children and adults }\end{array}$ & 60 & Scotland, Wales \\
\hline $\begin{array}{l}\text { 4. To encourage government to give } \\
\text { proper respect to children's views }\end{array}$ & 74 & Iceland, Norway \\
\hline $\begin{array}{l}\text { 5. To promote the rights of particular } \\
\text { groups of disadvantaged children }\end{array}$ & 87 & England, Iceland \\
\hline $\begin{array}{l}\text { 6. To promote a higher priority for } \\
\text { children and positive public attitudes }\end{array}$ & 88 & - \\
\hline $\begin{array}{l}\text { 7. To promote children's access to } \\
\text { complaints processes }\end{array}$ & 92 & Georgia, Hungary, Portugal, Slovakia \\
\hline
\end{tabular}

Overall, the top priorities of ENOC members were 'to influence law, policy and practice', 'to promote full implementation of the CRC' and 'to promote awareness of children's rights among children and adults'. As the respondent from Slovakia put it: 'even in countries where the CRC is fully implemented in legislation, there is a problem in realization of legislation in practice and the daily work of state bodies and authorities'.

Some members found it difficult to separate the different aims, and some insisted on giving equal rankings to all the aims. The lowest priority overall was to promote children's access to advocacy and complaints processes. However, this was the first priority of all but one associate 
members of ENOC who deal with individual complaints; these institutions regard dealing with individual complaints as their main duty, and a measurable outcome.

The reluctance of some members to rank their priorities may suggest difficulty in selecting one or two aims when they are expected to undertake ' $360^{\circ}$ monitoring' of childhood. ${ }^{3}$

\section{Children's participation}

Hart's 'ladder of children's participation' (1992) was used to explore the strategies of ENOC members for engaging with children. Institutions were asked to identify which rung on the ladder best described the level of children's engagement in their work. Table 3 shows that the most common response was 'Children consulted and informed', followed by 'Adult-initiated, shared decisions with children'. Six respondents gave multiple answers, indicating that they worked on more than one level. On reflection, the results might have been more precise if the questionnaire had asked institutions to identify their highest level of child participation.

\section{Table 3. Estimated levels of children's participation}

\begin{tabular}{|c|c|c|}
\hline Rung on Hart's ladder & Number & Institutions claiming this level \\
\hline $\begin{array}{l}\text { Child-initiated, shared } \\
\text { decisions with adults }\end{array}$ & 4 & Northern Ireland, Norway, Sweden, Wales \\
\hline $\begin{array}{l}\text { Child-initiated and } \\
\text { directed }\end{array}$ & 3 & Georgia, Serbia, Wales \\
\hline $\begin{array}{l}\text { Adult-initiated, shared } \\
\text { decisions with children }\end{array}$ & 8 & $\begin{array}{l}\text { Belgium, Iceland, Luxembourg, Netherlands, Norway, } \\
\text { Serbia, Vojvodina, Wales }\end{array}$ \\
\hline $\begin{array}{l}\text { Children consulted and } \\
\text { informed }\end{array}$ & 15 & $\begin{array}{l}\text { Belgium, Bosnia, Croatia, Cyprus, Finland, Georgia, } \\
\text { Greece, Lithuania, Luxembourg, Netherlands, Norway, } \\
\text { Serbia, Slovakia, Srpska, Wales }\end{array}$ \\
\hline $\begin{array}{l}\text { Children assigned but } \\
\text { informed }\end{array}$ & 2 & Luxembourg, Portugal \\
\hline Tokenism & 0 & - \\
\hline Decoration & 1 & Latvia \\
\hline Manipulation & 0 & - \\
\hline
\end{tabular}

There was no obvious regional pattern, except perhaps that the four countries claiming to work at the highest level were all from the UK or Scandinavia. Armenia and Italy, newly-formed

\footnotetext{
${ }^{3}$ Interview with Trond Waage, 2014. Trond Waage was Norway's Ombudsman for Children from 1996 to 2004 and initiated the foundation of ENOC.
} 
institutions, reported no level of child participation as yet. Another new member, Latvia, chose 'decoration' and aimed at 'correcting their weak point'. These responses show an impressive honesty about self-perceived weaknesses.

Some members expressed a preference for Treseder's (1997) 'Degrees of Participation' as a 'non-hierarchical, dynamic conception of children's participation and a useful reference point for the flexible approach towards work with children' (Ireland).

\section{Networking}

Networking was an important mechanism for most members. In particular, the networking opportunities offered by ENOC membership were valued as an opportunity to compare experiences and exchange information. Membership also brought links with European bodies such as the Council of Europe and with international standards, gave improved credibility and confidence, and helped to create a space for Youth Panel Advisors. Both experienced and newer institutions reported these benefits, and there were no obvious regional patterns.

\section{Outcomes}

In this section we asked open questions about the impacts that institutions were aiming for, the impact they estimated they had made or were making, and their approach towards evaluating their impact.

\section{Expected impact}

The survey included an open question about where the ENOC members expected their work to have significant impact. Responses were sorted into four categories which reflected the leading priorities of most ENOC members: Influencing law and policy; Promoting protection and provision rights; Promoting participation rights; Raising awareness of children's rights. The results are shown in Table 4. The highest expectation of impact was in relation to 'Implementing protection and provision rights', followed by 'Raising awareness of children's rights', 'Influencing law and policy' and 'Implementing participation rights', in that order. Differences between the four scores were small.

Table 4. ENOC members' expectations of impact (coded by aim) 


\begin{tabular}{|c|c|c|c|c|}
\hline & $\begin{array}{l}\text { Promoting } \\
\text { protection and } \\
\text { provision rights }\end{array}$ & $\begin{array}{l}\text { Raising awareness } \\
\text { of children's rights }\end{array}$ & $\begin{array}{l}\text { Influencing law and } \\
\text { policy }\end{array}$ & $\begin{array}{l}\text { Promoting } \\
\text { participation rights }\end{array}$ \\
\hline Armenia & $x$ & & & $x$ \\
\hline Belgium & & & $x$ & \\
\hline Bosnia & $x$ & $x$ & $x$ & \\
\hline Croatia & $x$ & & & \\
\hline Cyprus & $x$ & $x$ & $x$ & $x$ \\
\hline England & $x$ & $x$ & & $x$ \\
\hline Finland & & $x$ & $x$ & $x$ \\
\hline Georgia & $x$ & $x$ & $x$ & $x$ \\
\hline Greece & & & $x$ & 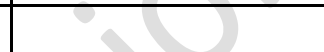 \\
\hline Hungary & & & $x$ & 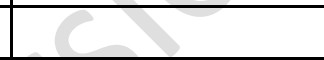 \\
\hline Iceland & & $x$ & & 2 \\
\hline Ireland & $x$ & & $x$ & 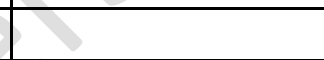 \\
\hline Italy & $x$ & & 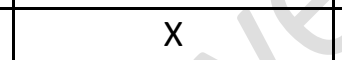 & 8 \\
\hline \multicolumn{5}{|l|}{ Latvia } \\
\hline Lithuania & $\mathrm{X}$ & $x$ & $C$ & \\
\hline Luxembourg & $x$ & $x$ & 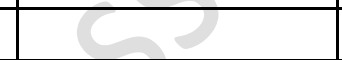 & $x$ \\
\hline Netherlands & $x$ & & 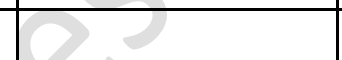 & \\
\hline N. Ireland & & +3 & 3 & $x$ \\
\hline Norway & & 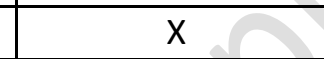 & $x$ & \\
\hline Portugal & $x$ & +2 & $x$ & \\
\hline Srpska & & $x$ & & $x$ \\
\hline Scotland & $x$ & $x$ & & $x$ \\
\hline Serbia & & $x$ & & $x$ \\
\hline Slovakia & $\mathrm{X}$ & 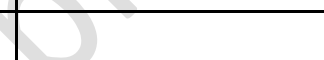 & $x$ & \\
\hline Slovenia & $x$ & 8 & & \\
\hline Sweden & $x$ & & & \\
\hline Vojvodina & $x$ & & & \\
\hline Wales & $x$ & & & \\
\hline Total & 17 & 14 & 12 & 10 \\
\hline
\end{tabular}

\section{Actual impact}

A related question asked where ENOC members actually saw impact from their work. Responses were divided into the same four categories. The results (Table 5) show that, compared to their expectations, institutions' actual impact was substantially greater for 'Influencing law and policy', rather less in relation to 'Promoting protection and provision rights', and remarkably low in relation to 'Promoting participation rights'.

Table 5. Most significant actual impacts on children (coded by aim) 


\begin{tabular}{|c|c|c|c|c|}
\hline & $\begin{array}{l}\text { Influencing law } \\
\text { and policy }\end{array}$ & $\begin{array}{l}\text { Raising } \\
\text { awareness of } \\
\text { children's rights }\end{array}$ & \begin{tabular}{|l} 
Promoting \\
protection and \\
provision rights
\end{tabular} & $\begin{array}{l}\text { Promoting } \\
\text { participation } \\
\text { rights }\end{array}$ \\
\hline Armenia & $x$ & $\mathrm{x}$ & & \\
\hline Belgium & $x$ & $\mathrm{x}$ & & \\
\hline Bosnia & $x$ & $x$ & & $x$ \\
\hline Croatia & & $x$ & & \\
\hline Cyprus & $x$ & $x$ & $x$ & \\
\hline England & $x$ & $x$ & $x$ & \\
\hline Finland & & $x$ & & $x$ \\
\hline Georgia & $x$ & & & $x$ \\
\hline Greece & $x$ & $x$ & $x$ & $x+y$ \\
\hline Hungary & $x$ & & & 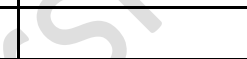 \\
\hline Iceland & & & $x$ & 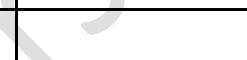 \\
\hline Ireland & $x$ & & $\mathrm{x}$ & 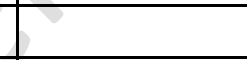 \\
\hline \multicolumn{5}{|l|}{ Italy } \\
\hline Latvia & $x$ & $x$ & 8 & \\
\hline Lithuania & $x$ & & $x$ & \\
\hline Luxembourg & $x$ & & (2) & \\
\hline \multicolumn{5}{|l|}{ Netherlands } \\
\hline N. Ireland & & $x$ & & \\
\hline Norway & $x$ & $\overline{s+1}$ & & \\
\hline Portugal & $x$ & 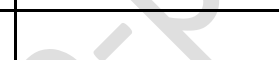 & $x$ & \\
\hline Srpska & & $x$ & $x$ & \\
\hline Scotland & & $x$ & $x$ & \\
\hline Serbia & $\mathrm{x}$ & + & & \\
\hline Slovakia & $x$ & $\mathrm{x}$ & & \\
\hline Slovenia & $e^{2}$ & & & \\
\hline Sweden & $x$ & & & \\
\hline Vojvodina & 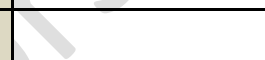 & & $x$ & \\
\hline \multicolumn{5}{|l|}{ Wales } \\
\hline Total & 17 & 13 & 10 & 3 \\
\hline
\end{tabular}

Responses to the question about actual impact were also categorised according to the particular services or settings for different children to which they related (Table 6). The commonest responses related to school, child welfare, youth justice and the care system, followed by child abuse, corporal punishment and child poverty.

Table 6. Most significant actual impacts on children (coded by service or setting)

\begin{tabular}{|l|l|l|l|l|}
\cline { 2 - 4 } \multicolumn{1}{l|}{} & School & Child Welfare & Youth Justice & Care System \\
\hline Armenia & & & & \\
\hline
\end{tabular}




\begin{tabular}{|l|c|c|c|c|}
\hline Belgium & & $\mathrm{X}$ & $\mathrm{X}$ & \\
\hline Bosnia & & & & \\
\hline Croatia & & & & \\
\hline Cyprus & & & & \\
\hline England & $\mathrm{X}$ & $\mathrm{X}$ & $\mathrm{X}$ & \\
\hline Finland & $\mathrm{X}$ & & & \\
\hline Georgia & & & & $\mathrm{X}$ \\
\hline Greece & $\mathrm{X}$ & $\mathrm{X}$ & & \\
\hline Hungary & & & & \\
\hline Iceland & & & & \\
\hline Ireland & $\mathrm{X}$ & $\mathrm{X}$ & $\mathrm{X}$ & \\
\hline Italy & & & & \\
\hline Latvia & $\mathrm{X}$ & & $\mathrm{X}$ & \\
\hline Lithuania & & & & $\mathrm{X}$ \\
\hline Luxembourg & $\mathrm{X}$ & & $\mathrm{X}$ & \\
\hline Netherlands & & & & \\
\hline N. Ireland & & & & \\
\hline Norway & & & & \\
\hline Portugal & $\mathrm{X}$ & & $\mathrm{X}$ & \\
\hline Srpska & & & & \\
\hline Scotland & & & & \\
\hline Serbia & & & & \\
\hline Slovakia & & & & \\
\hline Slovenia & & & & \\
\hline Sweden & & & & \\
\hline Vojvodina & & & & \\
\hline Wales & & & & \\
\hline Total & $\mathbf{6}$ & & \\
\hline
\end{tabular}

Examples of impact included: free education for all children; support for young people leaving care; 'a clear ban against physical and mental abuse of children'; 'making children visible and having their voices heard'; special education allowances and safety requirements in playgrounds.

The mismatches in responses to the question about priorities and to those about impact may have a number of explanations. In some cases the questions may have been misunderstood, or the answers may reflect inconsistencies in thinking. In others it may be that the operation of mechanisms in context means that outcomes develop differently from what was anticipated, or that it is easier to have impact in one area than in another.

Target groups for impact 
Respondents were asked whether they aimed for impact on particular groups of children: an open question to which responses are shown in Table 7. The most common areas of focus were children in care and children with disabilities. Some reported that they did not target any particular groups: 'we focus on all children... if policy is child-friendly for all children, it is also good for the most disadvantaged in our society'; others that their focus changes each year: 'This year's work focuses on children who experience domestic violence. Last year we worked with children and young people living in care homes or foster homes'.

Table 7. Target groups of children for impact

\begin{tabular}{|c|c|c|c|c|c|c|c|}
\hline & $\begin{array}{l}\text { Disabled } \\
\text { and SEN }\end{array}$ & $\begin{array}{l}\text { Living in } \\
\text { Poverty }\end{array}$ & \begin{tabular}{|l|} 
In \\
Conflict \\
with Law
\end{tabular} & $\begin{array}{l}\text { In Care } \\
\text { Svstem }\end{array}$ & $\begin{array}{l}\text { Abused/ } \\
\text { Domestic } \\
\text { Violence }\end{array}$ & Minority & $\begin{array}{l}\text { Refugee/ } \\
\text { undocumented }\end{array}$ \\
\hline Armenia & $x$ & $x$ & & $\mathrm{x}$ & 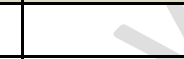 & & $\mathrm{x}$ \\
\hline Belgium & & & & & e & 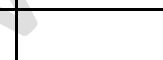 & \\
\hline B\&H & $x$ & & & $x$ & 0 & $x$ & \\
\hline Croatia & $x$ & $x$ & $x$ & & $x$ & $x$ & \\
\hline Cyprus & $x$ & & & $x$ & & & $x$ \\
\hline England & $x$ & $x$ & $x$ & $\infty$ & & $x$ & $x$ \\
\hline Finland & $x$ & & $\mathrm{~s}$ & $x$ & & $x$ & \\
\hline Georgia & $x$ & $x$ & & $x$ & $x$ & $x$ & \\
\hline Greece & $x$ & C & $x$ & $x$ & $x$ & $x$ & $x$ \\
\hline Hungary & $x$ & 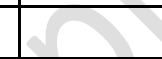 & & $x$ & & $x$ & \\
\hline Iceland & 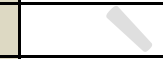 & P & & & & $x$ & \\
\hline Ireland & P & $x$ & $x$ & & & & \\
\hline Italy & 20 & $x$ & $x$ & & $x$ & & $x$ \\
\hline Latvia & $x$ & & $x$ & $x$ & & & \\
\hline \multicolumn{8}{|l|}{ Lithuania } \\
\hline \multicolumn{8}{|l|}{ Luxembourg } \\
\hline Netherlands & & & & $x$ & $x$ & & $x$ \\
\hline N. Ireland & & & $x$ & $x$ & & & \\
\hline Norway & & & & $x$ & $x$ & & $x$ \\
\hline \multicolumn{8}{|l|}{ Portugal } \\
\hline Srpska & & & & $x$ & & & \\
\hline Scotland & $x$ & $x$ & & & $x$ & & \\
\hline Serbia & $x$ & & & & & $x$ & \\
\hline Slovakia & & & & $x$ & & & \\
\hline \multicolumn{8}{|l|}{ Slovenia } \\
\hline Sweden & & & $x$ & $x$ & $x$ & & \\
\hline Vojvodina & $x$ & $x$ & & & & $x$ & \\
\hline Wales & $x$ & & $x$ & $x$ & & $x$ & \\
\hline
\end{tabular}




\begin{tabular}{|l|l|l|l|l|l|l|l|}
\hline Total & 14 & 8 & 9 & 16 & 9 & 11 & 7 \\
\hline
\end{tabular}

\section{Experiences of evaluating impact}

Fourteen IHRICs reported that they had undergone no evaluation. It is likely that recently established offices were not yet ready to evaluate their impact (eight of these institutions had been established in the six years preceding the survey). Among longer established institutions, lack of funds and of staff were the main reasons given, suggesting that resource constraints may be reducing the potential for IHRICs to reflect and evaluate their work. Of those institutions who had undergone evaluation, some conducted internal evaluation using monitoring frameworks and performance indicators, while others experienced external evaluations by a variety of organisations (Table 8).

Table 8. Institutions reporting internal or external evaluation

\begin{tabular}{|l|l|}
\hline Internal Evaluation & External Evaluation \\
\hline Belgium & Croatia \\
\hline Georgia & England \\
\hline Hungary & Northern Ireland \\
\hline Lithuania & Norway \\
\hline Serbia & Portugal \\
\hline Sweden & Scotland \\
\hline & Wales \\
\hline
\end{tabular}

The measures which institutions used in evaluating their impact varied widely according to local context. Indicators used included: implementation of the CRC, number of individual complaints, number of changes to the law, relationships with stakeholders and being consulted by policy and law makers. Other criteria that respondents would like to use were: positive public attitudes, adoption of suggestions made, willingness of children and adults to consult them, and children's satisfaction with their work. Institutions whose functions included individual casework tended to focus on this element; casework tends to have concrete results that can be measured quantitatively, and offices can clearly see the impact.

Institutions reported that evaluation had helped them in promoting children's participation, drafting action plans, achieving legislative change, identifying gaps in their profile and promoting dialogue with Parliament. Problems in evaluating their work included difficulty in isolating their impact from that of other organisations and evaluations not producing sufficient detail. 


\section{Willingness to take part in further research}

Participants in the survey were invited to say whether they would be willing to participate in the second phase of the study; 12 indicated that they would. The process of selection is outlined below.

\section{Introduction to the case study}

The survey showed, amongst other things: that a range of contextual factors made a difference to how institutions operated and what they could achieve; that the mechanisms used by IHRICs to achieve their objectives were also mixed (and in particular that the level of children's participation varied considerably); that their principal objectives were generally around 'influencing law and policy', 'full implementation of the CRC', and 'raising awareness of children's rights'; and that for most institutions their expected impacts related to those objectives, but that actual impacts were often different, and that these differences were substantial in $60-70 \%$ of cases. The survey had shown important contextual factors for the work of institutions to be their staff, mandate and independence, frameworks and networks, especially NGOs. Impact was sought in terms of full implementation of the UNCRC, influencing law and policy, and raising awareness of children's rights. Following this, the case study phase focused on evaluating the organisations' impact on law and policy, and also on how this was informed by children's perspectives.

Alongside the conceptual framing of critical realism, the case study approach drew on the methods of Appreciative Inquiry (AI) which have been applied by social researchers to evaluate and improve organisational functioning (Cooperrider and Srivastva, 1987). AI focuses on assets, to make positive change, and seeks the 'secrets of success' in working units (Cooperrider et al., 2003). It is not claimed that this research fully employed the methods of AI. The experience of the survey showed that institutions were concerned about being judged as ineffective, and often felt that they had not benefited from previous research projects. The aim was to make evaluation a reflexive learning process for IHRICs, rather than assessing them, often negatively, against predetermined standards. Regarding the acknowledged weakness of AI in understanding political context and power relations (Squirrell, 2012), the hope was that 
the critical realist approach, and the attention to C-M-O configurations, would enable those elements to be scrutinised.

Informal discussions with ENOC members at the annual conference in 2012 established that two members, who we will call 'the Ombudsman' and 'the Commissioner', were particularly keen to take part. Since together they met many of our selection criteria, we agreed to accept their respective offers. Although both are ICRIs rather than IHRICs, and both were established at much the same time, there were also important differences in their mandate (the Commissioner takes individual cases, the Ombudsman not), funding and staffing (the Commissioner is much better resourced), and particular contextual issues (conflict and poverty for the Commissioner, welfare state and municipalities for the Ombudsman). Finally, the Commissioner's jurisdiction is an autonomous region whilst the Ombudsman's is a nation state.

A specific research proposal was offered to each of the two institutions, clarifying the process and outcomes (including a full report at the conclusion). This explained that the work would comprise three main stages, which we set out as follows:

(i) An exchange of ideas with your core team to develop the detailed plan for the case study, so that this is a collaborative evaluation from the start, and to identify key sources and informants;

(ii) A data gathering phase in which we propose to interview selected staff in your team and some of your stakeholders (including the youth panel advisors, NGOs and representatives of Government), as well as examining relevant documents related to your work; initial analysis will be largely concurrent with data collection;

(iii) A third stage in which we will share our findings with you, complete the analysis, and will help you to plan for future work and further evaluation.

In studying the Ombudsman we interviewed the Ombudsman and six staff, eleven adult stakeholders (see Table 9) and four young people - three members of the youth panel and one from a 'survivors group'. In studying the Commissioner we interviewed the Commissioner and seven senior staff, eleven adult stakeholders (see Table 10) and two young people - a former member of the youth panel and a current member of the Participation Awards Group.

Table 9: Adult stakeholders interviewed (Ombudsman) 


\begin{tabular}{lcccccc}
\hline SECTOR & $\begin{array}{c}\text { Govt } \\
\text { Depts }\end{array}$ & NGOs & Municipalities & $\begin{array}{c}\text { Other } \\
\text { Ombudsmen }\end{array}$ & Universities & $\begin{array}{c}\text { Religious } \\
\text { Organisations }\end{array}$ \\
\hline $\begin{array}{l}\text { Number of } \\
\text { participants }\end{array}$ & 2 & 2 & 2 & 2 & 2 & 1 \\
\end{tabular}

Table 10: Adult stakeholders interviewed (Commissioner)

\begin{tabular}{lccccc}
\hline SECTOR & Govt Depts & NGOs & Legal Professionals & Universities \\
\hline Number of participants & 2 & 5 & 2 & 2
\end{tabular}

The resulting data thus comprised the survey responses from the two institutions, relevant documents (including action plans, annual reports and other publications), interviews (audio recorded and transcribed) and field notes. The case study research was carried out during 2013, with an extended visit to each site and further contact by telephone.

\section{Introducing the two institutions}

Both case study institutions were established in the mid 2000s as a result of the efforts of civil society, with the active support of the Committee on the Rights of the Child. A wide range of NGOs working for children had supported their establishment and their continuing work. The Commissioner has more extensive powers and enjoys a more generous budget, despite being established in a region that suffers from poverty. The Ombudsman, although in a more affluent and egalitarian society, has struggled with shortages of resources and staff, and has had more issues with its independence. Both institutions have an organisational structure whose main components are policy and research, legal work, and participation. Each institution has sought to establish a youth panel in an advisory role, and to make it inclusive and representative. The background of both the Commissioner and the Ombudsman is in the political field.

In the survey of ENOC members, the Ombudsman ranked their principal aims as follows:

1) To promote full implementation of the CRC;

2) To promote a higher priority for children and more positive public attitudes; 
3) To encourage government to give proper respect to children's views;

4) To influence law and policy.

The Commissioner ranked their principal aims and priorities as follows:

1) To promote full implementation of the CRC;

2) To influence law, policy and practice;

3) To encourage government to give proper respect to children's views;

4) To promote awareness of children's rights (among children and adults).

Both case studies began by interviewing the head of the institution. The Ombudsman, who was the country's first, recalled that:

When we started, we did not have any knowledge about the work of Ombud [here] and even in other places. We are such a small office with five people and not enough money for wide projects. So, I decided to stress on impacting the structures with my good contacts and skills to impact decision makers. Although law, policy and practice are very inter-connected, we have mostly worked on changing the policies and practices.

The Commissioner had succeeded the original postholder, who had this to say about starting up (in the first annual report):

When I took up the post I had no staff, no office and... one of the key tasks facing me was finding the right office, in the right place, with the right design. As with most of the work involving the Commissioner, children and young people led the way... A panel of 12-18 year olds told us they wanted a location close to public transport links, with access directly from the street, finished to create a welcoming environment and with specific spaces for children and young people... After a lengthy process, we identified [...] as our best option.

However, some years later the Government asked the Commissioner to move to less expensive premises outside the city centre.

\section{Strategies of the two institutions}


The underlying strategy of the Ombudsman was described in the following way by a member of staff:

Here, the problem is not the law, but mostly gaps in practices, especially in municipality levels... [as] each municipality decides for its own... If the government would co-ordinate better, in different municipalities children would get more or less the same services. The Office has always referred to the CRC and that there should not be differences in their rights and welfare.

The Commissioner has adopted a series of action plans, based on research and consultation which identify priority areas for action. Over time this process has seen a reduction in the number of priority areas and a shift closer to the Commissioner's legislative remit. The stated priorities at the time of the research were:

1) Raise awareness of children's rights and the functions of the Commissioner amongst children, parents and other stakeholders;

2) Review and advise the Government on policies, services and legislation relating to children's rights;

3) Use the Commissioner's powers to challenge breaches of children and young people's rights;

4) Ascertain the views of children and young people in relation to issues which affect their lives;

5) Maximise the Commissioner's impact and corporate performance.

Both institutions pursue their aims through some combination of the following activities:

1) Raising awareness of children's rights: both institutions use websites, publications, training and public events. The Ombudsman aims these efforts particularly at the municipal level:

Municipalities can decide on many things according to the framework the Government provides them... Now, their awareness is raised and they try to listen to children. It took many years for the decision makers to understand that, but if the Office was not there they would not have understood it yet.

The Ombudsman's websites for school age children and for adults are available in several languages. In 2013 the adult version had 55,000 visitors and the children's version 25,000. A manual provides basic information on children's human rights and 
contains training packs for children.

The Commissioner's website attracts almost 150,000 visits a year, and is a resourcefor people seeking information about the lives of children and young people. During 2007-10, the communications and participation team worked with almost 8,000 children and young people, explaining the work of the Commissioner, discussing the UNCRC and explaining its relevance for every child and young person. The team is proactive in encouraging and securing media coverage. A 'Train the Trainers' programme began in teacher training colleges and expanded into youth and community work; the Commissioner has since developed a Masters in Education module on Children's Rights. Awareness levels among children remain low - a government evaluation in 2010 used a survey designed by Thomas et al. (2010) and found that just under $30 \%$ of school pupils had heard of the Commissioner.

2) Monitoring and protecting children's rights: This is done through periodic reports to the Committee on the Rights of the Child in addition to dealing with individual cases (Commissioner) or providing advice and referrals to individuals (Ombudsman), and monitoring provision and protection services for children, e.g. by assessing children's influence on children's welfare services.

The Ombudsman is not mandated to receive and investigate complaints from children and did not consider it necessary at the time to expand the mandate in this way, as it would require detailed groundwork and additional human resources. Instead:

We are working with the Parliamentary Ombudsman and NGOs and our lawyer... to show the need for more child law centres, hotlines and child friendly complaint making process... and the Parliamentary Ombudsman [to ask children during] investigations of services... We are trying to offer them some guidelines on how to ask children about their issues.

The Commissioner works with Children's Commissioners in neighbouring jurisdictions to report on progress on the UNCRC. The Commissioner does deal with individual complaints:

A lot of [our] work is based on the individual cases that we get on a daily basis. Very often, cases can be resolved by making a phone call, writing a letter or making an intervention. That makes the outcome much quicker and 
much more positive. However, if that does not happen, we have the opportunity to take legal action of some kind.

The Commissioner's legal and investigative powers are used to identify gaps in service provision or legal loopholes, intervene in legal cases which concern children's rights, and take strategic cases as appropriate to highlight and challenge failures. As the CEO reported:

The majority of cases have been coming from education and SEN. ${ }^{4}$ As well as SEN, there is the issue with bullying and cyber bullying. But there have been also cases on health, transport issues, housing and disabilities.

Over the past 10 years, an average of 650 enquiries had been dealt with each year. Usually, complaints came from parents, carers or young people themselves. The Commissioner also receives initial referrals from solicitors, youth workers, politicians, social workers and school teachers.

The Commissioner at the time of the research had two interventions before the European Court of Human Rights, concerning respectively a child's right to privacy and to education. This is believed to be the first time a Children's Commissioner or Ombudsman has been granted leave to appeal to the European Court of Human Rights. The case involving a child's right to education is one where the Commissioner also intervened in the Supreme Court.

3) Legislative and policy work: This is done through scrutinising government delivery for children, strengthening child-friendly structures, improving administration and coordination between departments and ministries and providing advice to government on matters concerning children and submitting statements.

The Ombudsman has tried to increase the country's cooperation with the Council of Europe, seeking comparative standards on a regional level and across Europe. In 2010, the Ombudsman initiated discussion about new ways of organizing children and young people and family issues with the government. The focus of the discussion was introducing a Child and Family Minister in order to coordinate the various Ministries and ensure that the child and family do not fall between administrative sectors. The Ombudsman has also sought to strengthen the children's viewpoint on consumer

\footnotetext{
${ }^{4}$ Special Educational Needs.
} 
policy. Cooperative work on the issue of children as consumers was carried out with the Consumer Ombudsman; as a result, the legislation was amended to add specific protection for children.

According to the Ombudsman, one of their main ways of influencing law and policy has been through working with groups of Ministries: "It is a good way of impacting as it is in the early phases of decision-making process. And offices are more open in these cases". According to research participants, the Ombudsman's office tended to adjust their statements to the climate of decision making, personalities of individual politicians and attitudes of different organisations.

The Commissioner has developed a 'child rights impact assessment' process for assessing government strategies, and has recommended that this process should be integrated into those used by government. Additionally, the Commissioner has reviewed the Government's strategy for children and young people and the associated action plan. The Commissioner is seeking to engage with key departments more proactively on significant issues affecting children, earlier on in the policy development process. For example, in an educational project, the Commissioner made a 'timely response' to the Department of Education consultation and offered to assist the Minister by consulting with children and young people to explore their views and experiences of shared education among students from different communities.

While the Ombudsman prefers working on policy rather than law, the Commissioner's policy and research team sometimes finds that:

Advising on pieces of legislation happens quicker than policy because policy change is a very slow process. But legislation does have a more limited time frame and there is more public engagement and more scrutiny of Assembly. So, it is possible to have a little bit more of impact on legislation than perhaps on policy.

4) Networking: This is done both at national and European levels, with members of Parliament, government, NGOs and other regional and European IHRICs. The Ombudsman declares their most important partners to be decision makers with strategic mandates, such as party leaders and key negotiators of government platform, in addition to national NGOs working for children's protection and well-being and the National Youth Council. One important partner is the main Protestant church, whose 
service organisations for children and young people work to influence the rights of the child within the church. The Ombudsman's European co-operation extends both to neighbouring countries and the ENOC network. Members of the regional council of Ombudsmen for Children work closely together.

The Commissioner tries to build on the positive working relationship with politicians, NGOs and other statutory organisations in the public sector, particularly the human rights commission and the equality commission, and children's commissioners and ombudsmen in neighbouring jurisdictions. In addition,

ENOC networking helps me share skills and experiences from other European countries, giving me the opportunity to share with other Ombudspersons some of my good practice, especially with regards to participation.

5) Children's participation: Both institutions encourage their respective governments to enable children and young people's participation in decisions that affect their lives and to develop creative and accessible mechanisms for listening to and engaging children and young people.

The Ombudsman has advocated a focus on children's say in parental divorce and separation, continuing contacts on children's issues with municipal Ombudsmen, providing children's perspectives for the development of school curricula, and promoting the inclusion of children's perspectives in various reforms within government administration. The Ombudsman defines children and young people's participation in terms of mutual learning, respect and appreciation. The Ombudsman considers children as experts on their lived experiences, and produced a handbook of guidance for decision-makers on how to consult with children. The office works with the Children's Parliament and a 'Survivors Group' of young people with experience of alternative care. The Ombudsman also has a youth advisory group, but both staff and stakeholders considered that it tends to represent 'more privileged young people'.

The Commissioner has a regular programme of visits to schools and events to meet children and young people. However, an independent review voiced stakeholders' concerns about lack of direct contact by the Commissioner with the most vulnerable and disadvantaged children, including those in care or detention, refugee and migrant children, children with disabilities or additional needs. There were also criticisms from NGOs that the youth panel did not do enough to represent disadvantaged groups. The 
panel are recruited on a rolling basis by peer selection; there are no reserved places for particular groups of children and young people. Members are involved in direct meetings with Ministers, among other activities. Young advisors have also been heard at European level with presentations to ENOC and other international connections.

\section{Examples of good practice identified by participants and researchers}

The Ombudsman and Commissioner, their staff and other stakeholders were invited to point to particular actions, activities or projects that had proved effective and had made a difference in law, policy or practice. From these we selected a number of exemplary projects, based on the following criteria:

- Children and young people's participation;

- Innovation and good timing (combining reactivity and proactivity)

- Use of the distinctive powers of IHRICs (and where appropriate good use of individual complaints)

- Networking and empowering NGOs

- Developing structures for children and young people's participation

- Positive ethos (hope and appreciation)

For the Ombudsman, two projects in particular stood out:

1. The 'Care Tour' - this took an existing group of young adult 'survivors' of the care system around the country to meet children and young people in care and give them an opportunity to share their experiences. This led to the production of a handbook for children and young people in alternative care which has been distributed widely. A young person from the group recalled:

'When we saw [the Ombudsman] we realized that some people wanted to listen to us. She forwarded our experiences to the policy makers and [took us to meet] the child-friendly politicians. After the meeting there was a session in the Parliament and politicians discussed about making or changing a law. So it was bang on time. If she had not come to see us, we would have still been doing the meetings in our small group and small NGO.' 
Outcomes of the tour included an invitation for a member of the survivors group to join a Ministry working group set up to improve child welfare services, and a decision to include them in investigations of care homes. The report of the tour is used in practitioner training, and a second tour directed at adults was being planned at the conclusion of our research. The Ombudsman identified the success factors as follows:

'Networking was a crucial issue. It was also a new way to think about children having their own thoughts. There was also demand for this in child protection. We also had young people working with us from the beginning, so it was a long standing co-operation. In addition to our national partners, we had these very key people in local areas that were interested in taking part but I would mention young people as the most influential.'

Some impressive features of this project are: face-to-face contact with children; young people with experience of the care system empowering children in care; supporting an NGO by using the powers of the Ombudsman; building on a project initiated by others instead of starting a similar activity of their own; and a timely reaction to a tragic failure of the care system (the death of a child) which amplified the impact of the tour.

2. Child Friendly Municipalities - this project began with a survey in which 140 children aged 9 to 14 years of age from different municipalities took part. The aim was to obtain information on how local government services appear to children, and how they feel they can influence the affairs of their municipality. In all $42 \%$ of children said that they had no influence on decisions. Municipal services that mattered to children most were: school, sports and recreation, library, public transport and health care. Participants said that a municipality fit for children and young people to live should have opportunities for learning, moving, playing, hobbies and eating well, a safe living environment and adults with the right attitudes towards children and young people who are interested in children and young people's opinions.

After the survey, a group of children and young people from municipalities who had experience of participation made a statement for decision makers, a workshop was led by young people for officials in the Ministry of Finance who were responsible for municipality reform, and a leaflet containing information on how to listen to children was delivered to every municipality. 
The survey provided a basis for further networking and lobbying. The Ombudsman was a member of the Ministry working group for municipal reform, and there raised the issue of children and young people's participation. The group eventually proposed that municipalities should have obligatory youth councils, and agreed to study a possibility to lower the voting age to 16 .

For the Commissioner, four projects were identified:

1. Goods, Facilities and Services - this project arose from the realisation that proposed age discrimination legislation to cover provision of goods, facilities and services did not extend to children and young people under 18. For example, young people complained that they were made to leave their schoolbags outside shops or were not allowed to enter shops at certain times or in groups; they also reported problems with home rental, gym entrance and access to other public facilities. The Commissioner consulted its young advisors, who campaigned in the media to challenge discrimination against children and young people. The Office started an online petition to be sent to the Government, has had ongoing liaison with relevant statutory agencies and coworked on a policy paper with other stakeholders. As a result, meetings have been arranged with the relevant politicians, the working group of the Parliament has agreed to inform the members of the Parliament and the public has supported the project. The impact of this project will be reduced negative stereotyping of children and young people and amendment of current issues in relation to age-appropriate services.

The strengths of this project included:

Effective targeting of decision-makers

Solidly built on previous activities with children and young people

Good timing

High level of children and young people's participation

- Extensive networking

- Grounded in children and young people's everyday lives and experiences.

2. Speech and language therapy - this project emerged from the high number of complaints received by the Commissioner about these services. A review was carried out under legislation which gives the Commissioner power to review the adequacy and effectiveness of services provided for children and young people by relevant 
authorities. The review showed that standards of service and waiting times for children and young people varied widely across the country, and action research in one area generated recommendations for how to improve. A further review the following year showed that children were still waiting to access services. The Commissioner threatened to carry out a formal investigation, and to avoid this the Health Department put additional funding into the service, and established a taskforce which made further recommendations. After some delay this activity resulted in a 'speech language and communication strategy' which included commitments to develop a regional commissioning framework, establish partnership agreements between departments and reduce waiting times. The project was identified as an example of good practice on account of:

- Proactive use of the institution's legal powers

- Using individual cases to influence law and policy

- Sustained follow-up

- Significant improvement to services

- Well-judged research which showed the gaps and indicated solutions

- An effective combination of case work and response to consultation

3. Participation Awards - these were established in order for young people to identify and reward best practice in the public sector in enabling participation of children and young people in decisions and policies that affect them. It followed from a 'participation policy statement of intent' developed by the Commissioner which at the time of the research had been adopted by a total of 26 Government departments and other public bodies. The award panel comprised a diverse group of young people who together developed criteria for the awards and then judged the applicants, according to the values of 'engage, listen, rights, voice, respect, involve, equality, change'. Applications were received from a wide range of government departments and public bodies working in the fields of health, arts, justice, transport, public safety and regulation. Feedback from young people was that they felt strongly involved in the development of the awards process and in recognition of good practice. In an evaluation survey, applicants responded that it had been very encouraging to see so many organisations involving children and young people in decision-making, and that the awards highlighted the good work being done in the area of youth participation and encouraged more organisations to provide meaningful opportunities for young people 
to get involved in decision-making. The project was identified as an example of good practice on account of:

- Innovation

- Appreciative approach to recognise positive achievements

- Follow-up of the 'statement of intent' by preparing structures for children and young people's participation

4. Suspension from school - this was a court case brought by a child against school suspension processes which had failed to allow the child a voice. The Commissioner intervened when the case reached the Supreme Court, to assist with the legal arguments, and then in the European Court. The suspension was eventually declared to be illegal, and the Commissioner then engaged with government to ensure that new guidance was issued to education authorities. This project is included to show how work in individual cases can successfully impact on law and policy.

\section{Evaluation of impact by research participants}

When asked to evaluate the impact of the organisation on law, policy and practice, participants in both case studies pointed mainly to the greater visibility and priority of children's issues in policy-making, greater participation, and raised awareness of children's rights. The Ombudsman reported that 'the most significant impact... has been more emphasis and encouragement on the participation rights of children.' The Commissioner identified the most significant impact as: 'making children visible and having their voices heard and reflected in the decisions on a daily basis'; the CEO stated: 'I think the most impact has been in the various departments of Government that consider the voices and lives of children and young people, especially those excluded from education, in care, in prison, in poverty.'

Staff of the two institutions had some difficulty in pointing clearly to specific impacts. In the case of the Ombudsman, staff thought: it was too early; the office had not undergone any evaluation; isolating their impact from the other actors was difficult; and recording and following up their work was not practiced consistently. In the case of the Commissioner 'Change comes very slow... We should be realistic about what we can do. We don't have our hands on the policy levers. We are about challenging, persuading and advising.' 
Nor was it easy for stakeholders to identify impact of the institutions. Sometimes their knowledge of the activities and achievements of the Offices appeared insufficient. However, they mostly thought that both institutions had helped in changing mindsets and identifying gaps in the implementation of children's rights.

There were also some negative views:

'the impact of [the Ombudsman] is very mediated impact... they don't have any power other than questioning and reporting children's situation.'

'I don't think [the Commissioner has] had an impact on... law or policy, e.g. the age of criminal responsibility. They've had some high profile events rather than significant impact on law and policy.'

When asked what was needed for a stronger impact, stakeholders' responses could be categorised as follows:

1. Raising awareness of children's rights: Participants thought that more work was needed on CRC education at schools, both for children and professionals. It was suggested that for children living with difficulties, awareness raising campaigns should be ongoing rather than ad hoc events, and that all professionals working with/for children should be trained systematically.

2. Monitoring and protecting children's rights: It was recommended that children's services should be monitored and supervised more by both institutions. The Commissioner was advised to be more involved in the courts and perform more formal investigations.

3. Legislative and policy work: Participants thought that the institutions should focus more on policy work and long term changes, and do 'general things for public instead of academic research'.

4. Networking: It was suggested that more collaboration with NGOs and human rights actors and the institutions' advisory boards were needed in addition to 'more networking with university experts especially in childhood studies and children's rights field'. 
5. Children's participation: It was suggested that for a stronger impact on law and policy, institutions should improve children's participation through 'getting the participation policy into legislation', searching for effective methods of listening to children and young people in difficulties, and changing the way their youth panel advisors are elected and run.

The above suggestions were common to both cases. Particular points were also raised in relation to each institution by the participants: for the Ombudsman, increasing the independence of the institution by its being supervised by the Parliament instead of Ministries and especially by providing more staff and resources; for the Commissioner, review of the founding legislation, particularly in relation to class action and duplication, and realising and using the powers to their maximum.

\section{Conclusion: a tool for impact assessment}

It is hoped that this research has advanced the methodology of evaluation of independent children's rights institutions by taking account of the very different legal, political, social, economic and cultural contexts of such institutions. This means that their practical aims, their choices of priorities and their realistic possibilities for impact are also different, so that impact evaluation has to be highly contextual. Finding the best way to evaluate them demands familiarity with their contexts, and spending time on reflection within the institutions themselves. In contrast to earlier single case studies that focused on macro narratives of success, we compared institutions in their micro and macro narratives and sought to appreciate their achievements and strengths, whilst maintaining a critical approach to evaluation. We also suggested that instead of attempting to isolate their impact from the other child rights actors they focus on their unique mandates and how they have applied them in making an imapact.

Our research confirmed that the impact of such institutions has to be assessed in the specific context of each institution. Whilst comparisons can be useful, standard measures of effectiveness are unlikely to be of much use when the context is so variable and complex, and when objective attribution of effect is so difficult. This does not mean that common tools 
cannot be developed and may not be useful; in the concluding phase of this research we began to develop one such tool, testing it with our case study institutions.

Our impact evaluation tool follows the approach taken in this research: identify the institutions' resources and supports in their particular contexts, identify effective mechanisms and document outcomes, using realistic evaluation and appreciative inquiry. What proved helpful in the case study was to look in depth at effective individual projects and best practices of the institutions. Therefore we propose a tool that enables institutions to reflect on a series of such 'micro-evaluations', to understand where they have real impact and what works well for them. An impact evaluation tool should be flexible, enabling institutions to learn about their assets and reflect on what they could do better. It should also have the capacity to be employed from the early stages of planning an activity right through to the long-term outcome. It should have a focus on children and young people's participation, and it should demand clear evidence of the impacts claimed.

The proposed tool is an evaluation template in which immediate, medium and long-term impacts (Sayer, 2000) are all included. It draws on work by Cutt and Murray (2000), Dunford (2010) and the International Council on Human Rights Policy (2005), and has been reviewed with international experts in the work of IHRICs. It is designed to be used in planning, performing, documenting, evaluating and reporting projects and activities. Institutions are recommended to evaluate their impact by tracking the progress of individual projects in some detail. The tool can also be used by researchers or external evaluators who wish to perform systematic, in-depth, comparative and collaborative impact evaluations of IHRICs. It is intended to assist IHRICs and their stakeholders to create a culture of thinking critically about their work and constantly seeking to improve performance (Coffman, 2007). This generally requires an organisation to become more self-conscious about its role and influence (International Council on Human Rights Policy, 2009). The template and guidance are available at https://www.uclan.ac.uk/research/explore/groups/assets/evaluationtemplate.docx.

Our research has shown that IHRICs, notwithstanding their powers and great potential to improve the rights of children, are vulnerable institutions, representing as they do a social group (children) who are not generally considered to be competent citizens. Their independence may be threatened by political and economic factors, and they depend on partner organisations for 
much of their impact. Children's Commissioners and Ombudsmen face huge tasks and expectations, so prioritising their aims is difficult. They risk becoming so busy engaging in reactive and proactive activities that they can neglect to take a systematic approach to their objectives or pause to think about their impacts and achievements.

They are also, potentially, powerful and effective institutions. At their commencement, most IHRICs faced uncertainty about how best to fulfil their new role and meet the heavy expectations on them. Gradually they have learned how to produce good practice with significant impacts, through a distinctive combination of applying their unique powers, innovation, lobbying and facilitating children's conversations with policy makers and service providers. This last seems particularly important. The study showed that institutions can act as interlocutors between children and the State by empowering both to engage in more effective dialogue, and so enable children to have real impact on policy. IHRICs' most noticeable impacts have often been in changing mindsets about children's rights, and in promoting children's participation in influencing law, policy and practices regarding children. This has potential to develop into a process of 'mutual empowerment' where IHRICs, rather than representing children and young people's views to powerful adults, focus on facilitating them to represent themselves.

\section{References}

Bhaskar, R. (1997) A Realist Theory of Science (3rd ed.), London: Verso.

Bhaskar, R. (1998) The Possibility of Naturalism: A Philosophical Critique of the Contemporary Human Sciences ( ${ }^{\text {rd }}$ edition). London: Routledge.

Coffman, J. (2007) 'What's Different about Evaluating Advocacy and Policy Change?' The Evaluation Exchange XIII(1), 2-4.

Committee on the Rights of the Child (2002) General Comment No. 2: The role of independent national human rights institutions in the promotion and protection of the rights of the child (CRC/GC/2002/2). United Nations.

Cooperrider, D.L. and Srivastva, S. (1987) 'Appreciative Inquiry in Organisational Life', in W. Pasmore and R. Woodman (Eds) Research in Organisation Change and Development (Vol.1) Greenwich, CT: JAIPress.

Cooperrider, D., Whitney, D., and Stavros, J. (2003) Appreciative Inquiry Handbook: The First in a Series of AI Workbooks for Leaders of Change, Bedford Heights, $\mathrm{OH}$ : 
Lakeshore Publishers.

Cutt, J. and Murray, V. (2000) Accountability and Effectiveness Evaluation in non-Profit Organizations, London: Routledge.

Doek, J. E. (2008) Independent Human Rights Institutions for Children (Innocenti Working Paper No. 2008-06), Florence: UNICEF Innocenti Research Centre.

Dunford, J. (2010) Review of the Office of the Children's Commissioner (England), London: Department for Education.

ENOC (2001) Standards for Independent Children's Rights Institutions (http://enoc.eu/wpcontent/uploads/2015/01/ENOC-Standards-as-approved-Paris-01.pdf, accessed 19/02/2017).

Hart, R. (1992) Children's Participation: From Tokenism To Citizenship, Florence: UNICEF.

Hewitt, G., Sims, S. and Harris, R. (2012) 'The realist approach to evaluation research: an introduction', International Journal of Therapy and Rehabilitation 19(5), 205-259.

International Council on Human Rights Policy (2009) Human Rights Organisations: Rights and Responsibilities. Versoix, Switzerland: International Council on Human Rights Policy.

International Council on Human Rights Policy and Office of the United Nations High Commissioner for Human Rights (2005) Assessing the Effectiveness of National Human Rights Institutions, Geneva: ICHRP and OHCHR.

Lansdown, G. (2001) Independent Institutions Protecting Children's Rights (Innocenti Digest No. 8). Florence: Innocenti Research Centre.

Mayall, B. (2002) Towards a Sociology for Childhood: Thinking from Children's Lives. Buckingham: Open University Press.

Pawson, R. and Tilley, N. (1997) Realistic Evaluation. Sage: London.

Robson, C. (2013) Real World Research (3 ${ }^{\text {rd }}$ edition). Oxford: Blackwell.

Sayer, A. (2000) Realism and Social Science, Sage: London.

Sedletzki, V. (2013) Championing Children's Rights A global study of independent human rights institutions for children, Florence: UNICEF Office of Research.

Squirrell, G. (2012) Evaluation in Action: Theory and Practice for Effective Evaluation, Dorset: Russell House Publishing.

Thomas, N., Cook, M., Cook, J., France, H., Hillman, J., Jenkins, C., Pearson, T., PughDungey, R., Sawyers, B., Taylor, M. and Crowley, A. (2010) 'Evaluating the Children's Commissioner for Wales: Report of a participatory research study', International Journal of Children's Rights 18(1), 19-52.

Thomas, N., Gran, B. and Hanson, K. (2011) 'An independent voice for children's rights in Europe? The role of independent children's rights institutions in the EU'. International 
Journal of Children's Rights 19(3), 429-449.

Treseder, P. (1997) Empowering Children and Young People, London: Children's Rights Office and Save the Children.

United Nations (1993) Principles relating to the Status of National Institutions

(http://www.ohchr.org/EN/ProfessionalInterest/Pages/StatusOfNationalInstitutions.aspx, accessed 19/02/2017).

\section{Acknowledgements}

The authors are grateful for the assistance of the ENOC secretariat and its member institutions in making this research possible, and to all those who contributed to the case study. We also wish to thank colleagues at the University of Central Lancashire and in the International Research Group on Ombudspersons for Children. Dr Imanian received financial support from the University of Central Lancashire and from Funds for Women Graduates, which she acknowledges with thanks.

\section{Accepted for publication $5^{\text {th }}$ February 2019.}

